\title{
EFFECTS OF CARNOSINE AND LIPOIC ACID IN THE LATE STAGE OF PARKINSON'S DISEASE IN RATS
}

Berezhnoy DS, Fedorova TN, Kulikova OI $\bowtie$, Stavrovskaya AV, Abaimov DA, Gushchina AS, Olshansky AS, Voronkov DN, Stvolinsky SL

Research Center of Neurology, Moscow, Russia

The late stage of Parkinson's disease is characterized by massive neuronal loss in the substantia nigra (SN) and degeneration of the dopaminergic innervation in the striatum. There is a need to assess the neuroprotective effect of antioxidants (AO) at this stage of the disease. The aim of our study was to assess the efficacy of two $A O$, carnosine and lipoic acid (LA), in the rat model of late-stage parkinsonism. The pathology was induced by a unilateral injection of 6 -hydroxydopamine (6-OHDA) into the SN of the right brain hemisphere. AO were administered 4 times, starting on day 14 following the injection of the toxin. We investigated the effect of the injected drugs on the behavior of rats, the loss of neurons in the SN and the metabolism of biogenic neurotransmitter amines. Both AO dampened the development of 6-OHDA-induced neurological and behavioral symptoms. 6-OHDA induced a 90\% drop ( $p=0.01)$ in the levels of dopamine (DA) and its metabolites in the right striatum and caused death of over $95 \%$ of neurons $(p=0.01)$ in the SN of the right hemisphere $(p=0.01)$. AO did not have a significant effect on the number of neurons in the SN but caused an increase in the levels of DA metabolites, as compared to their levels in the animals exposed to 6-OHDA. Elevated DA (a 5.8-fold increase, $p=0.007$ ) was observed only in the animals treated with carnosine. LA stimulated a $23 \%$ decline in serotonin levels $(p=0.06)$ and a $36 \%$ increase $(p=0.009)$ in its metabolite, 5 -hydroxyindolacetic acid $(5-H \mathrm{AA})$. We conclude that although carnosine and $L A$ did not have a direct neuroprotective effect, they could relieve the symptoms. This suggests that these AO could be used as an adjunctive component to antiparkinsonian therapy.

Keywords: parkinsonism, Wistar rats, carnosine, lipoic acid, neurotransmitters, behavioral tests

Author contribution: Berezhnoy DS analyzed the literature; planned the study; acquired, analyzed and interpreted the obtained data; prepared the draft of the manuscript and revised its final version. Fedorova TN analyzed the literature; planned the study; analyzed and interpreted the obtained data; revised the manuscript. Kulikova OI analyzed the literature; planned the study; acquired, analyzed and interpreted the obtained data; revised the manuscript. Stavrovskaya AV analyzed the literature; planned the study; acquired, analyzed and interpreted the obtained data; prepared the draft of the manuscript. Abaimov DA acquired, analyzed and interpreted the obtained data; prepared the draft of the manuscript. Gushchina AS planned the study; acquired, analyzed and interpreted the obtained data; prepared the draft of the manuscript. Olshansky AS acquired and analyzed the data; prepared the draft of the manuscript. Voronkov DN acquired analyzed and interpreted the obtained data; prepared the draft of the manuscript. Stvolinsky SL planned the study; acquired, analyzed and interpreted the obtained data; prepared the draft of the manuscript.

Compliance with ethical standards: all experiments involving the use of animals were conducted in full compliance with the international Guide for the Care and Use of Laboratory Animals.

$\triangle$ Correspondence should be addressed: Olga I. Kulikova

Volokolamskoe shosse, 80, Moscow, 125367; kulikova@neurology.ru

Received: 12.08.2019 Accepted: 30.08.2019 Published online: 18.09.2019

DOI: 10.24075/brsmu.2019.060

\section{ДЕЙСТВИЕ КАРНОЗИНА И ЛИПОЕВОЙ КИСЛОТЫ В МОДЕЛИ ПОЗДНЕЙ СТАДИИ БОЛЕЗНИ ПАРКИНСОНА У КРЫС}

Д. С. Бережной, Т. Н. Федорова, О.И.Куликова $\bowtie$, А. В. Ставровская, Д. А. Абаимов, А. С. Гущина, А. С. Ольшанский, Д. Н. Воронков, С. Л. Стволинский

Научный центр неврологии, Москва, Россия

Оценка эффективности антиоксидантных (АО) препаратов при введении на поздней стадии экспериментального паркинсонизма в условиях тотальной гибели нейронов черной субстанции (ЧС) и нарушений дофаминергической иннервации стриатума является актуальной проблемой. Целью исследования было оценить эффективность АО карнозина и липоевой кислоты (ЛК) в модели поздней стадии паркинсонизма. Паркинсонизм индуцировали у крыс с помощью унилатерального стереотаксического введения 6-гидроксидофамина (ГДА) в ЧС правого полушария. АО вводили 4 раза, начиная с 14-го дня после введения токсина. Изучали влияние препаратов на поведение, гибель нейронов чС и метаболизм медиаторовмоноаминов. Оба препарата снижали развитие неврологической симптоматики и нарушения поведения, вызванные ГДА. Введение ГДА приводило к снижению уровня дофамина (ДА) и его метаболитов в правом стриатуме на 90\% (p=0,01) и гибели более 95\% нейронов в ЧС правого полушария $(p=0,01)$. АО значимо не влияли на количество нейронов в ЧС, но увеличивали содержание метаболитов ДА относительно животных, получавших ГДА, при этом повышение содержания ДА (в 5,8 раз; $p=0,007)$ наблюдали только у животных, получавших карнозин. Введение ЛК способствовало снижению серотонина на 23\% ( $p=0,006)$ и его метаболита 5-гидроксииндолуксусной кислоты (ГИУК) на 36\% (p=0,009). Таким образом, при отсутствии прямого нейропротекторного эффекта было обнаружено симптоматическое действие карнозина и ЛК, что обосновывает возможность их использования в качестве дополнительной терапии болезни Паркинсона.

Ключевые слова: паркинсонизм, крысы линии Wistar, карнозин, липоевая кислота, нейромедиаторы, физиологическое тестирование

Информация о вкладе авторов: Д. С. Бережной - анализ литературы, планирование исследования, подготовка черновика рукописи и финального варианта статьи; Т. Н. Федорова — анализ литературы, планирование исследования, подготовка финального варианта статьи; О. И. Куликова анализ литературы, планирование исследования, подготовка финального варианта статьи; А. В. Ставровская - анализ литературы, планирование исследования, подготовка черновика рукописи; Д. А. Абаимов - подготовка черновика рукописи; А. С. Гущина - планирование исследования подготовка черновика рукописи; А. С. Ольшанский - подготовка черновика рукописи; Д. Н. Воронков - подготовка черновика рукописи; С. Л. Стволинский - планирование исследования, подготовка черновика рукописи; все авторы участвовали в сборе, анализе и интерпретации данных.

Соблюдение этических стандартов: все эксперименты с животными проводили в соответствии с международными правилами работы с лабораторными животными.

$\triangle$ Для корреспонденции: Куликова Ольга Игоревна Волоколамское ш., д. 80, г. Москва, 125367; kulikova@neurology.ru

Статья получена: 12.08.2019 Статья принята к печати: 30.08.2019 Опубликована онлайн: 18.09.2019

DOI: $10.24075 /$ vrgmu.2019.060 
Parkinson's disease (PD) is a progressive neurodegenerative disorder characterized by the loss of dopaminergic neurons in the substantia nigra pars compacta (SNpc). There is no cure for PD, and the available treatments are symptomatic. This creates the need for effective neuroprotective agents capable of slowing or stopping the progression of the disease [1, 2].

6 -Hydroxydopamine (6-OHDA) is a selective catecholaminergic neurotoxin that gives rise to free radicals and inhibits complexes I and IV of the mitochondrial electron transport chain [3]. This compound is often used to induce PD in animal models. 6-OHDA injected into the SN of rats causes death of almost all striatal dopaminergic neurons and their terminals within 10 to 14 days after the injection [4]. Antioxidants (AO) administered to experimental animals before the injection or immediately after brain surgery have a remarkable neuroprotective effect [5], possibly resulting from their direct interaction with free radicals generated during 6-OHDA oxidation and, to some extent, from the effect they have on 6-OHDA autoxidation [6]. AO do not prevent the development of the pathology as such, but rather inactivate the neurotoxin that triggers the disease.

Carnosine and alpha-lipoic acid (LA) have been shown to be protective against neuronal damage in the early stage of induced parkinsonism in rats [7]. Bearing that in mind, it would be interesting to assess the efficacy of these $A O$ in later stages of PD when neuronal loss has already occurred and the dopaminergic innervation of the striatum has suffered some degeneration. This is when the definitive diagnosis is usually made and treatment starts.

The objective of this study was to assess the effect of carnosine and LA on rat behavior and the neurochemical parameters of rat brain in the late stage of 6-OHDA-induced parkinsonism.

\section{METHODS}

The study was conducted in 40 3-month old outbred male Wistar rats weighing 250 to $300 \mathrm{~g}$. The animals were housed under standard conditions (the 12/12 light/dark cycle) and had free access to food and water.

The rats were divided into 4 groups. Three experimental groups received a $3 \mu$ injection of $0.05 \%$ ascorbic acid solution containing $12 \mu \mathrm{g}$ of 6 -OHDA (Sigma; USA) into the substantia nigra at the start of the experiment. The control group consisted of sham-operated animals $(n=9)$ that received an equal amount of the solvent $(0.05 \%$ ascorbic acid). The stereotaxic coordinates for the injection were as follows: $\mathrm{AP}=-4.8$; $L=1.9 ; V=8.0$ [8]. For surgery, the rats were anesthetized with intramuscular injections of Zoletil $100(3 \mathrm{mg} / 100 \mathrm{~g})$ and xylazine (3 $\mathrm{mg} / \mathrm{kg}$ ); premedication with $0.04 \mathrm{mg} / \mathrm{kg}$ atropine was administered subcutaneously 10 to 15 min before xylazine. On days 14, 16, 18, and 20 following the 6-OHDA injection, the sham-operated animals $(n=9)$ received intraperitoneal injections of $0.9 \% \mathrm{NaCl}$ solution (this group will be referred to as $6-\mathrm{OHDA}+\mathrm{NaCl})$; groups 2 and $3(n=11$ and $n=11$, respectively) received intraperitoneal injections of $50 \mathrm{mg} / \mathrm{kg}$ carnosine (Swedlight AB; Sweden) and $50 \mathrm{mg} / \mathrm{kg}$ LA (ChemImplex Int'I Inc.; USA), respectively. Below, these 2 groups will be referred to as 6-OHDA+ carnosine and 6-OHDA+LA

The open field (OF) and the tapered beam walking (BW) tests were carried out on days 21 and 22 after the 6-OHDA injection to assess the behavior and locomotor activity of the animals. Because not all of them were able to make it to the end of the walking beam, we used an additional scale to assess their neurotic-like behavior (Table 1) [9] On day 25, the animals were decapitated using a guillotine (Open Science, Russia), their brains were removed and chilled on ice; the dorsal striatum of the left and right brain hemispheres and the SN-containing midbrain fragment were isolated for further histopathologic examination and immunostaining, respectively. The obtained samples were stored in liquid nitrogen.

\section{Quantification of dopaminergic neurons}

The number of dopaminergic neurons in the SN of the control animals and the $6-\mathrm{OHDA}+\mathrm{NaCl}$ group was estimated using an

Table 1. Points scored on the scale for assessing the neurotic-like behavior demonstrated in the beam walking test. The table describes the types and variations of different behaviors and the score for each type

\begin{tabular}{|c|c|c|}
\hline Behaviors & Elements & Score \\
\hline \multirow{5}{*}{ Self-grooming } & Nose-cheeks & 1 \\
\hline & Nose-cheeks-ears & 2 \\
\hline & Nose-cheeks-ears-belly & 3 \\
\hline & Nose-cheeks-ears-belly-back & 4 \\
\hline & $-/ /-+$ self-biting & 5 \\
\hline \multicolumn{3}{|l|}{ Movements } \\
\hline \multirow{4}{*}{ Head } & Sniffing & 1 \\
\hline & Left and right turns & 2 \\
\hline & Chewing & 3 \\
\hline & Licking & 3 \\
\hline \multirow{3}{*}{ Body } & Turn & 3 \\
\hline & Backing & 4 \\
\hline & Freezing & 5 \\
\hline \multirow{2}{*}{ Hangs over the beam } & Head & 1 \\
\hline & Half of the body & 2 \\
\hline Stops on the walking beam & & 3 \\
\hline Slips & & 2 \\
\hline Hiccups & & 4 \\
\hline
\end{tabular}


immunofluorescence staining technique for determining tyrosine hydroxylase (TH) content in the studied tissue [10]. TH is the key enzyme involved in dopamine synthesis. The specimens fixed in $4 \%$ formalin were soaked in sucrose and subsequently immersed in the O.C.T. Tissue Tek compound (Sigma; USA) Frozen frontal sections prepared from the specimens were $12 \mu \mathrm{m}$ thick in the SN region. The sections were incubated with $1: 800$ monoclonal rabbit anti-tyrosine hydroxylase antibodies (T8700, Sigma; USA) in a humidity chamber at room temperature for $24 \mathrm{~h}$. The binding of primary antibodies was visualized using goat CF488-conjugated antirabbit antibodies (Sigma, $1: 500$ ). The sections were mounted in the FluoroShield media (Sigma; USA), coverslipped and photographed under a Nikon Eclipse $\mathrm{Ni}-\mathrm{u}$ microscope (Nikon; USA) at $\times 10$ magnification. At least 8-10 sections per animal were studied, the distance between slices was 36-48 $\mu \mathrm{m}$. Neuronal bodies were counted in the field of view in ImageJ (NIH; USA).

\section{Concentrations of amine neurotransmitters and their metabolites}

The neurotransmitter amines and their metabolites measured in our study included dopamine (DA), 3,4-dihydroxyphenylacetic acid (DOPAC), homovanillic acid (HVA), 3-methoxytyramine (3-MT), noradrenalin (NA), serotonin (5-HT), and 5-hydroxyindoleacetic acid (5-HIAA). Their levels were determined in the right and left striatum using high-performance liquid chromatography with electrochemical detection (HPLCED). Measurements were done using a System Gold HighPerformance Liquid Chromatograph (Beckman Coulter Inc.; USA) equipped with an amperometric detector RECIPE EC 3000 (Recipe GmbH; Germany). The excised brain tissue was homogenized in 20 volumes of $0.1 \mathrm{~N} \mathrm{HClO} 4$ supplemented with $0.5 \mathrm{nmol} / \mathrm{ml}$ dioxybenzylamine, which was used as an internal standard. The tissue was centrifuged at 10,000 $\mathrm{g}$ for $10 \mathrm{~min}$. The supernatant was removed and analyzed [7].

\section{Statistical analysis}

The obtained data were processed in Statistica 10.0 (Dell. Inc.; USA). Significance of differences was assessed with ANOVA and Tukey's HSD. The samples were compared using paired Student's $t$-test and Mann-Whitney $U$ test, depending on the normality of data distribution. The differences were considered significant at $p<0.05$. The results are presented below as a mean value \pm the standard error $(\mathrm{M} \pm m)$.

\section{RESULTS}

\section{Analysis of neurological symptoms}

The beam walking test revealed pronounced behavioral symptoms in the rats that had been exposed to 6-OHDA
$(F(3.36)=10.54 ; p=0.001)$. All rodents from the control group successfully got to the end of the walking beam; the time it took them to cover the whole distance was $13.88 \pm 1.73$ seconds on average. However, only 3 of 11 animals from the $6-\mathrm{OHDA}+\mathrm{NaCl}$ group were able to reach the safety platform. Other rats demonstrated freezing behavior and could not finish the test. Therefore, we used an additional scale to assess the neurotic-like behavior of the animals (Table 2). The rats that had received carnosine or $L A$ did not have pronounced neurological symptoms. The post hoc analysis revealed no significant differences between any of these groups and the controls. At the same time, the differences between these 2 groups and the $6-\mathrm{OHDA}+\mathrm{NaCl}$ group were significant (Table 2).

No significant changes in horizontal activity were observed between the experimental groups in the OF test $(F(3.36)=1.83 ; p=0.16)$. However, paired sample comparison demonstrated significant differences between the control and the $6-\mathrm{OHDA}+\mathrm{NaCl}$ groups $(7.97 \pm 0.42$ and $4.21 \pm 0.77$, respectively; $p=0.001)$. ANOVA suggested a change in vertical activity $(F(3.36)=3.04 ; p=0.04)$. The post hoc analysis revealed that vertical activity was low only in the 6-OHDA+ $\mathrm{NaCl}$ group, in contrast to the animals who had been treated with carnosine or LA (Table 2).

\section{Quantification of dopaminergic neurons}

The number of dopaminergic neurons in SNpc was inferred from the immunohistochemical localization of $\mathrm{TH}$, the marker of dopamine neurons. Staining for TH was indicative of neuronal loss in the midbrain sections of all animals injected with 6-OHDA $(F(3.10)=6.33 ; p=0.01)$ (Fig. 1); it also showed that $A O$ had produced no therapeutic effect $(F(2.8)=0.51 ; p=0.61)$. For example, the examined regions of $\mathrm{SNpc}$ of the control animals contained an average of $166 \pm 48$ neurons, whereas all rats exposed to $6-\mathrm{OHDA}$ had only $4 \pm 2$ neurons $(p=0.01)$. These findings confirm the validity of our experimental model.

\section{Concentrations of amine neurotransmitters and their metabolites}

ANOVA results suggested that the levels of major amine neurotransmitters and their metabolites were changed in the right striatum only, where the neurotoxin had been injected $(\mathrm{F}(21.81)=3.29 ; p=0.001)$, in comparison with the left brain hemisphere $(F(21.69)=1.15 ; p=0.32)$. However, paired comparison of the $6-\mathrm{OHDA}+\mathrm{NaCl}$ and control groups revealed a significant increase in DOPAC (by $19.0 \pm 5.3 \%$ ) and HVA (by $19.1 \pm 3.8 \%$ ) concentrations in the left-brain hemisphere following the 6-OHDA injection (Fig. 2). Carnosine brought DOPAC levels down to the values registered in the control group.

The levels of DA and its major metabolites in the right striatum plummeted by an average of $90 \%$ in all animals

Table 2. The effects of carnosine and lipoic acid (LA) on rat performance in the tapered beam walking (BW) test and the open field (OF) test. The table shows the results of the post hoc Tukey's HSD test

\begin{tabular}{|l|c|c|c|}
\hline & BW score & Horizontal activity in OF (distance, $m$ ) & Vertical activity in OF (rearings, number of) \\
\hline Control group & $5.13 \pm 0.64$ & $7.97 \pm 0.42$ & $11.88 \pm 1.61$ \\
\hline $6-$ OHDA + NaCl & $13.60 \pm 1.53 \#$ & $4.21 \pm 0.77$ & $4.20 \pm 1.52 \#$ \\
\hline $6-O H D A+$ Carnosine & $7.18 \pm 1.05^{\star}$ & $6.32 \pm 1.38$ & $8.64 \pm 1.50$ \\
\hline 6-OHDA + LA & $5.27 \pm 1.27^{\star}$ & $6.16 \pm 1.14$ & $9.90 \pm 2.29$ \\
\hline
\end{tabular}

Note: * - difference from the 6-OHDA + NaCl group is significant, $p<0.05$; $\#$ - difference from the control group is significant, $p<0.05$. 
exposed to the neurotoxin regardless of the therapy they had received (Fig. 3). 3-MT concentrations demonstrated a less pronounced decline (by 58\%, on average).

Serotonin levels did not change significantly. 5-HIAA, one of serotonin metabolites, was elevated by $38 \%$ in the experimental groups, as compared to the controls (Fig. 4).

A 5.8-fold $(p=0.007)$ increase in the striatal DA content was observed in the animals treated with carnosine, relative to the $6-\mathrm{OHDA}+\mathrm{NaCl}$ group. The levels of DA metabolites (DOPAC and HVA) were elevated 3.4 -fold $(\rho=0.04)$ and 8.8 -fold $(p=0.01)$, respectively, following carnosine administration. LA injections caused a 4.7-fold $(p=0.03)$ and a 7.4 -fold $(p=0.04)$ increase in DOPAC and HVA, respectively (Fig. 3). The tested AO induced no changes in 3-MT levels. There was a $23 \%$ $(p=0.006)$ and $36 \%(p=0.009)$ decline in the concentrations of serotonin and its metabolite 5-HIAA, respectively, relative to the $6-\mathrm{OHDA}+\mathrm{NaCl}$ group. Carnosine did not have any effect on the levels of serotonin or its metabolites.

\section{DISCUSSION}

We attempted to comprehensively assess the effect of carnosine and LA on the performance of rats with induced parkinsonism in the behavioral tests and on the metabolism of DA and serotonin in the striatum. The pathology was induced by a unilateral injection of 6-OHDA into the SN; the first injection of $\mathrm{AO}$ was made on day 14 after surgery to prevent their effect on the autoxidation of the toxin and the occurred neuronal loss.

The death of neurons and ipsilateral striatal denervation were confirmed by immunohistochemistry (immunostaining of dopaminergic neurons in $\mathrm{SN}$ ) and a significant decline in

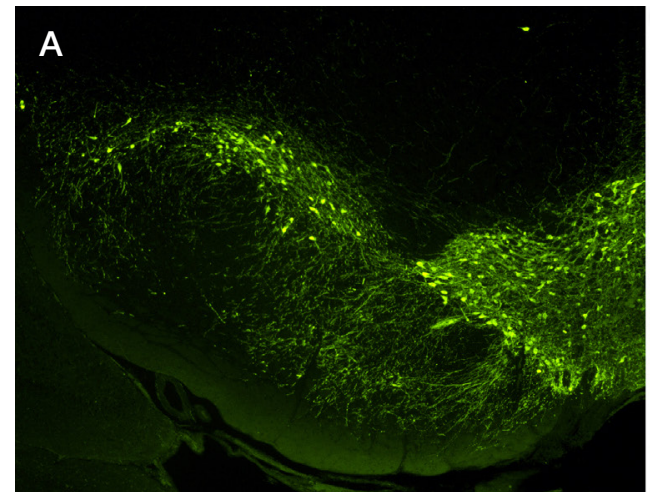

DA and its metabolites in the striatum of the right brain hemisphere, where the toxin had been injected. Regardless of the treatment applied, DA and its metabolites were lower in the animals exposed to 6-OHDA than in the control group. At the same time, carnosine and LA affected DA metabolism and caused an increase in DA metabolites, in comparison with the group of untreated 6-OHDA-exposed animals. However, DA levels were significantly elevated only in the group of animals treated with carnosine. Serotonin and 5-HIAA concentrations were lower in the group treated with LA than in the untreated 6-OHDA-exposed group. Considering that serotonin stimulates neurochemical mechanisms promoting motor dysfunction in PD and that low serotonergic neurotransmission in the basal ganglia has an antiparkinsonian effect [11], the impact of LA on serotonergic innervation may contribute to the improvement of motor function in parkinsonism.

Physiological tests revealed that neurological deficit and behavioral symptoms were significantly attenuated in the animals treated with both tested antioxidants. Four injections of carnosine and LA on days 14 through 20 of the experiment prevented the development of 6-OHDA-induced neurotic symptoms.

Studies involving the use of rat models of toxin-induced parkinsonism have demonstrated neuroprotective effects of both carnosine [12] and lipoic acid [13]. These drugs restored the antioxidant brain status and reduced peroxide oxidation. Besides, lipoic acid improved motor function in the affected animals [13]. However, in the studies cited above the drugs and the toxin were administered simultaneously and the loss of neurons in the SN was not assessed. This complicated interpretation of the results and left open the question about

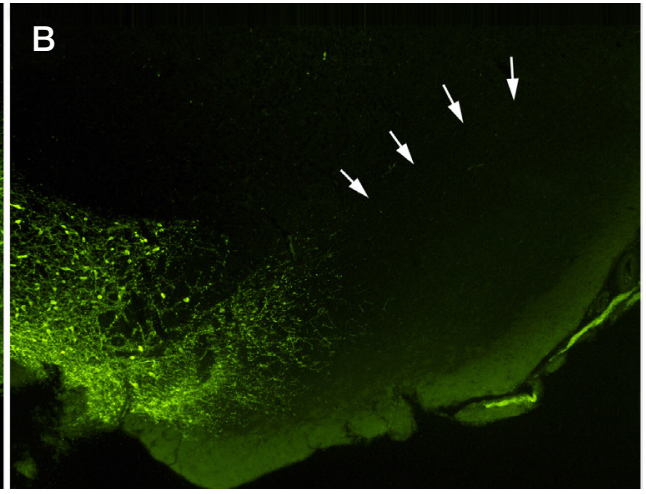

Fig. 1. Immunostaining for tyrosine hydroxylase in the $\mathrm{SN}$ of rats following the intranigral injection of 6-hydroxydopamine. A. Left brain hemisphere of an animal injected with saline. B. Right brain hemisphere of an animal injected with 6-OHDA. Arrows point to the region of neuronal loss in the SN at X10 magnification

DA

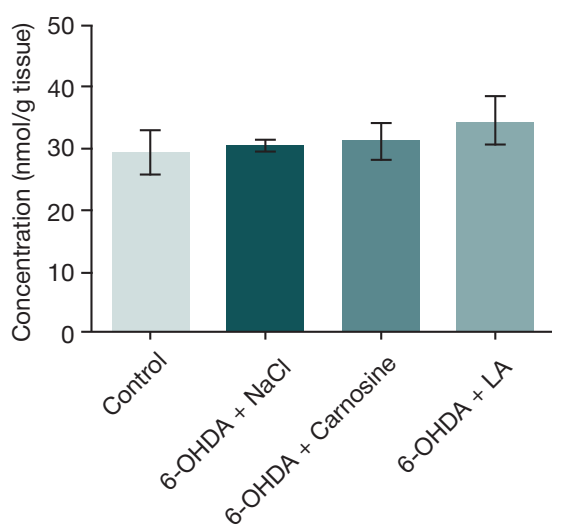

DOPAC

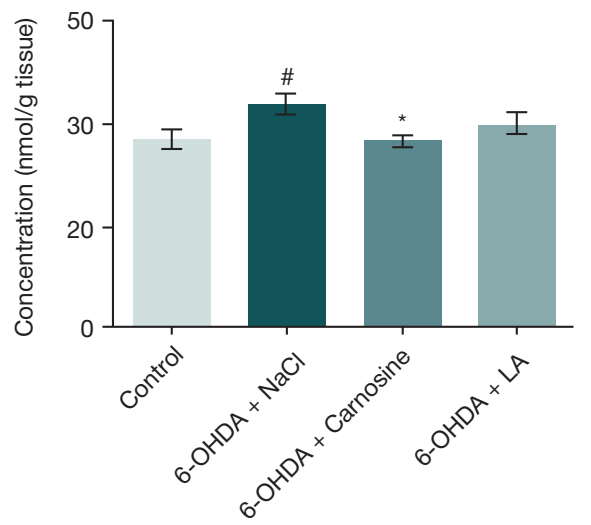

HVA

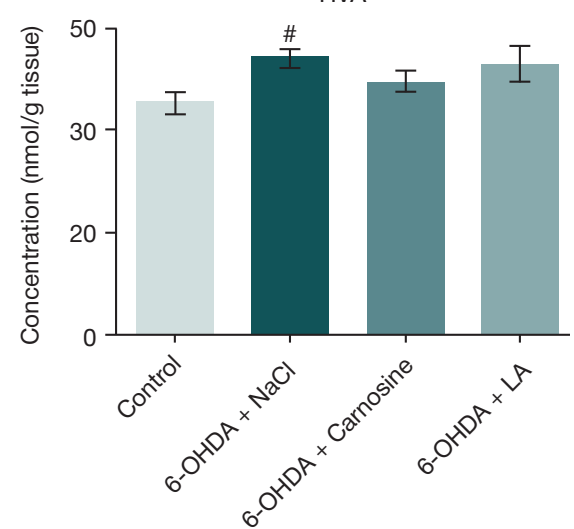

Fig. 2. Effects of carnosine and lipoic acid (LA) on the levels of dopamine (DA), 3,4-dihydroxyphenylacetic acid (DOPAC) and homovanillic acid (HVA) in the left striatum. \#- difference from the control group is significant, $p<0.05$; ${ }^{*}$ - difference from the $6-\mathrm{OHDA}+\mathrm{NaCl}$ group is significant, $p<0.05$ 

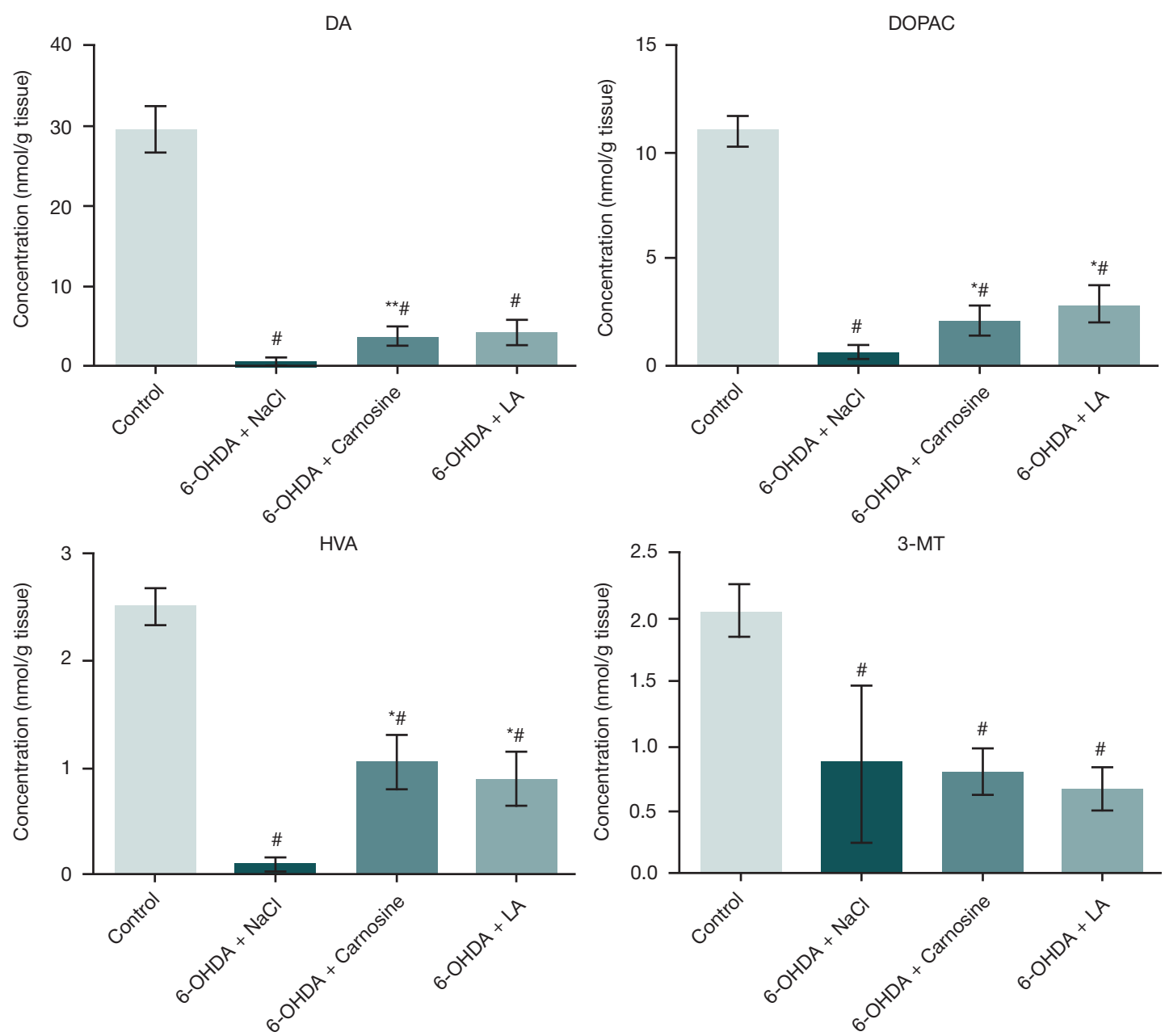

Fig. 3. Effects of carnosine and lipoic acid (LA) on the levels of dopamine (DA), 3,4-dihydroxyphenylacetic acid (DOPAC), homovanillic acid (HVA), and 3-methoxytyramine (3-MT) in the right striatum. \# - difference from the control group is significant, $p<0.05$; ${ }^{*}$ - difference from the $6-\mathrm{OHDA}+\mathrm{NaCl}$ group is significant, $p<0.05$; ** $-p<0.01$
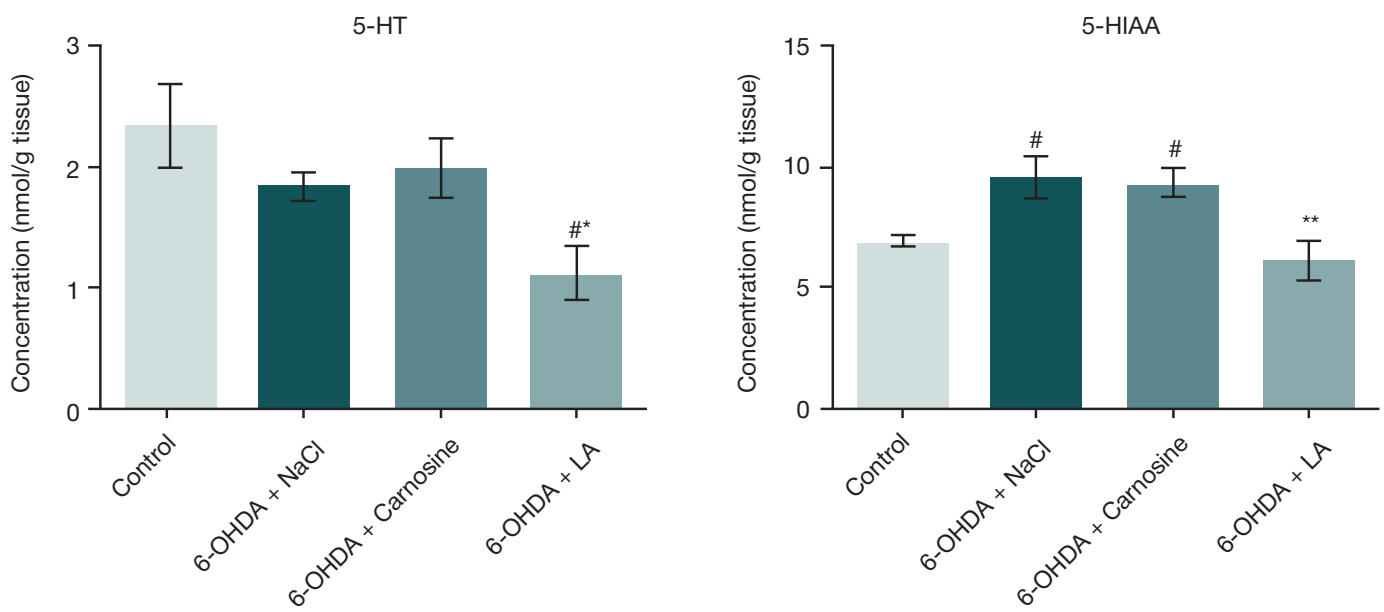

Fig. 4. Effects of carnosine and lipoic acid (LA) on the levels of serotonin (5-HT) and 5-hydroxyindoleacetic acid (5-HIAA) in the right striatum. \# — difference from the control group is significant, $p<0.05 ;{ }^{*}$ - difference from the 6-OHDA+NaCl group is significant, $p<0.05 ;{ }^{* *}-p<0.01$

the mechanisms of action of these compounds. Our study provides evidence of symptomatic relief produced by the tested drugs in the late stage of induced parkinsonism.

On the whole, our findings suggest that the tested antioxidants could be used as an adjunctive component to conventional antiparkinsonian therapy. Previously, lipoic acid was proposed for use in combination with levodopa [14], and the combination regimen of carnosine and levodopa was reported to be effective [15].

\section{CONCLUSOINS}

Although carnosine and LA did not have a direct neuroprotective effect, they attenuated parkinsonian symptoms due to a compensatory increase in the levels of DA and its metabolites and a simultaneous decrease in serotonin concentrations. Our findings suggest that the tested antioxidants could be used in combination with conventional antiparkinsonian drugs and provide a symptomatic relief. 
1. Sarkar S, Raymick J, Imam S. Neuroprotective and Therapeutic Strategies against Parkinson's Disease: Recent Perspectives. Int J Mol Sci. 2016; 17 (6): E904. DOI: 10.3390/ijms17060904. PMID: 27338353.

2. Illarioshkin SN, Slominsky PA, Shadrina MI, Bagyeva GKh, Zagorovskaya TB, Markova ED, et al. The heterogeneity of sporadic Parkinson's disease: a molecular approach to solving a problem. Annaly Klinicheskoy I Experimental'noy Nevrologii. 2007; 1 (1): 23-31. Russian.

3. Mazzio EA, Reams RR, Soliman KF. The role of oxidative stress, impaired glycolysis and mitochondrial respiratory redox failure in the cytotoxic effects of 6-hydroxydopamine in vitro. Brain Research. 2004; 1004 (1): 29-44.

4. Jeon BS, Jackson-Lewis V, Burke RE. 6-Hydroxydopamine lesion of the rat substantia nigra: time course and morphology of cell death. Neurodegeneration. 1995: 4 (2): 131-7.

5. Zbarsky V, Datla KP, Parkar S, Rai DK, Aruoma OI, Dexter DT. Neuroprotective properties of the natural phenolic antioxidants curcumin and naringenin but not quercetin and fisetin in a 6-OHDA model of Parkinson's disease. Free Radic Res. 2005; 39 (10): 1119-25. PMID: 7583676.

6. Soto-Otero R, Mendez-Alvarez E, Hermida-Ameijeiras A, Muñoz-Patiño AM, Labandeira-Garcia JL. Autoxidation and neurotoxicity of 6-hydroxydopamine in the presence of some antioxidants: potential implication in relation to the pathogenesis of Parkinson's disease. J Neurochem. 2000; 74 (4): 1605-12. DOI: 10.1046/j.1471-4159.2000.0741605.x. PMID: 10737618.

7. Kulikova OI, Berezhnoy DS, Stvolinsky SL, Lopachev AV, Orlova VS, Fedorova TN. Neuroprotective effect of the carnosine - alphalipoic acid nanomicellar complex in a model of early-stage Parkinson's disease. Regul Toxicol Pharmacol. 2018; 95: 254-9.
DOI: 10.1016/j.yrtph.2018.03.025. PMID: 2960191.

8. Paxinos G, Watson C. The Rat Brain in Stereotaxic Coordinates. 6th Edition. San Diego: Academic Press, 2006. 456 p.

9. Bolotova VTs, Krauz VA, Shustov EB. Biological model of experimental neurosis in laboratory animals. Biomedicina. 2015; (1): 66-80. Russian.

10. Khudoerkov RM, Voronkov DN, Dikalova YuV. Quantitative morphochemical characteristics of the neurons of the rat brain's substantia nigra and its volume reconstruction. Bull experiment biol and medicine. 2013; 156 (6): 861-4. Russian.

11. Kryzhanovsky GN, Magaeva SV, Trekova HA, Vetrila LA, Basharova LA, Atadzhanov MA. Participation of the serotonergic apparatus of the striatum in the Parkinsonian syndrome. Bull experiment biol and medicine. 1993; (5): 466-9. Russian.

12. Zhao J, Shi L, Zhang LR. Neuroprotective effect of carnosine against salsolinol-induced Parkinson's disease. Exp Ther Med. 2017; 14 (1): 664-70.

13. de Araujo DP, De Sousa CN, Araujo PV, Menezes CE, Sousa Rodrigues FT, Escudeiro S S, et al. Behavioral and neurochemical effects of alpha-lipoic Acid in the model of Parkinson's disease induced by unilateral stereotaxic injection of 6-OHDA in rat. Evid Based Complement Alternat Med. 2013; (1): 571-8.

14. Di Stefano A, Sozio P, Cocco A, lannitelli A, Santucci E, Costa M, et al. L-dopa- and dopamine-(R)-alpha-lipoic acid conjugates as multifunctional codrugs with antioxidant properties. J Med Chem. 2006; 49 (4): 1486-93.

15. Fedorova TN, Bagieva GH, Stepanova MS, Dobrotvorskaya MS, Ivanova-Smolenskaya IA, Polevaya EV, et al. Effectivity of carnosine in Parkinson's disease. Neurological bull. 2009; 41 (1): 24-9. Russian.

\section{Литература}

1. Sarkar S, Raymick J, Imam S. Neuroprotective and Therapeutic Strategies against Parkinson's Disease: Recent Perspectives. Int J Mol Sci. 2016; 17 (6): E904. DOI: 10.3390/ijms17060904. PMID: 27338353

2. Иллариошкин С. Н., Сломинский П. А., Шадрина М. И., Багыева Г. Х., Загоровская Т. Б., Маркова Е. Д. и др. Гетерогенность спорадической болезни паркинсона: молекулярный подход к решению проблемы. Анналы клинической и экспериментальной неврологии. 2007; 1 (1): 23-31.

3. Mazzio EA, Reams RR, Soliman KF. The role of oxidative stress, impaired glycolysis and mitochondrial respiratory redox failure in the cytotoxic effects of 6-hydroxydopamine in vitro. Brain Research. 2004; 1004 (1): 29-44.

4. Jeon BS, Jackson-Lewis V, Burke RE. 6-Hydroxydopamine lesion of the rat substantia nigra: time course and morphology of cell death. Neurodegeneration. 1995: 4 (2): 131-7.

5. Zbarsky V, Datla KP, Parkar S, Rai DK, Aruoma OI, Dexter DT. Neuroprotective properties of the natural phenolic antioxidants curcumin and naringenin but not quercetin and fisetin in a 6-OHDA model of Parkinson's disease. Free Radic Res. 2005; 39 (10): 1119-25. PMID: 7583676.

6. Soto-Otero R, Mendez-Alvarez E, Hermida-Ameijeiras A, Muñoz-Patiño AM, Labandeira-Garcia JL. Autoxidation and neurotoxicity of 6-hydroxydopamine in the presence of some antioxidants: potential implication in relation to the pathogenesis of Parkinson's disease. J Neurochem. 2000; 74 (4): 1605-12. DOI: 10.1046/j.1471-4159.2000.0741605.x. PMID: 10737618.

7. Kulikova OI, Berezhnoy DS, Stvolinsky SL, Lopachev AV, Orlova VS, Fedorova TN. Neuroprotective effect of the carnosine - alphalipoic acid nanomicellar complex in a model of early-stage Parkinson's disease. Regul Toxicol Pharmacol. 2018; 95: 254-9. DOI: 10.1016/j.yrtph.2018.03.025. PMID: 2960191.
8. Paxinos G, Watson C. The Rat Brain in Stereotaxic Coordinates. 6th Edition. San Diego: Academic Press, 2006. 456 p.

9. Болотова В. Ц., Крауз В. А., Шустов Е. Б. Биологическая модель экспериментального невроза у лабораторных животных. Биомедицина. 2015; (1): 66-80.

10. Худоерков Р. М., Воронков Д. Н., Дикалова Ю. В. Количественная морфохимическая характеристика нейронов черной субстанции мозга крысы и ее объемная реконструкция. Бюллетень экспериментальной биологии и медицины. 2013; 156 (6): 861-4.

11. Крыжановский Г. Н., Магаева С. В., Трекова Н. А., Ветрилэ Л. А., Башарова Л. А., Атаджанов М. А. Участие серотонинергического аппарата стриатума в паркинсоническом синдроме. Бюлл. эксперим. биол. и медицины. 1993; (5): 466-9.

12. Zhao J, Shi L, Zhang LR. Neuroprotective effect of carnosine against salsolinol-induced Parkinson's disease. Exp Ther Med. 2017; 14 (1): 664-70.

13. de Araujo DP, De Sousa CN, Araujo PV, Menezes CE, Sousa Rodrigues FT, Escudeiro S S, et al. Behavioral and neurochemical effects of alpha-lipoic Acid in the model of Parkinson's disease induced by unilateral stereotaxic injection of 6-OHDA in rat. Evid Based Complement Alternat Med. 2013; (1): 571-8.

14. Di Stefano A, Sozio P, Cocco A, lannitelli A, Santucci E, Costa M, et al. L-dopa- and dopamine-(R)-alpha-lipoic acid conjugates as multifunctional codrugs with antioxidant properties. J Med Chem. 2006; 49 (4): 1486-93

15. Федорова Т. Н., Багыева Г. Х., Степанова М. С., Добротворская И. С., Иванова-Смоленская И. А., Полевая Е. В. и др. Эфффективность карнозина при болезни Паркинсона. Неврологический вестник. 2009; 41 (1): 24-9. 